This is a self-archived - parallel published version of this article in the publication archive of the University of Vaasa. It might differ from the original.

\title{
IoT powered servitization of manufacturing - an exploratory case study
}

Author(s): Rymaszewska, Anna; Helo, Petri; Gunasekaran, Angappa

Title: $\quad$ IoT powered servitization of manufacturing - an exploratory case study

Year: $\quad 2017$

Version: Accepted manuscript

Copyright (C) 2017 Elsevier. Creative Commons AttributionNonCommercial-NoDerivatives 4.o International (CC BY-NCND 4.0) license, https://creativecommons.org/licenses/by-ncnd/4.0/

\section{Please cite the original version:}

Rymaszewska, A., Helo, P., \& Gunasekaran, A., (2017). IoT powered servitization of manufacturing - an exploratory case study. International journal of production economics 110, 92105. https://doi.org/10.1016/j.ijpe.2017.02.016 


\title{
IoT powered servitization of manufacturing - an exploratory case study
}

\begin{abstract}
With the rapid development of information technology and the Internet itself, companies are no longer confined within the information exchange between people, but they are expanding towards enabling communication between physical products.

This third wave of the Internet development referred to as the Internet of Things (IoT) unlocks the potential for innovative product-service systems in a scale that has not been observed before. Companies more than ever are challenged to rethink their offerings while simultaneously being provided with a unique opportunity of creating or recreating their product-service systems.

This article explores the potential for product-service development that IoT offers. By providing an overview of the technological breakthrough and its far reaching implications for different industries, as well as analyzing the literature on servitization, an attempt is made to combine those two concepts towards addressing the challenge of how organizations can actually reap the benefits that IoT has to offer in the product-service context. Moreover, an analysis of several successful IoT implementation cases in different industries is provided. As a result a conceptual framework for IoT implementation in product-service context is outlined.
\end{abstract}

\section{Introduction}

Technology is continuously transforming the ways companies operate by reshaping the nature of products, processes, strategies, business models, and competition (Porter, 1985; Porter and Heppelmann, 2014). Nowadays, organizations are gradually realizing that the possibility that the pursuit of long-term competitive advantage might no longer be attainable. On the other hand, the technological development is here to stay and this imply that only those flexible and fast-reacting players would have a real chance of reaping benefits that this development brings. This would allow for gaining a considerable competitive edge that might not last for too long, as the barriers of adopting IoT solutions are not high (Gubbi et al. 2013), but the array of strategic choices and business models is vast enough to accommodate numerous new entrants, 
provided they are able to quickly and proactively grasp the opportunities that this third wave of IT-driven development brings.

The nature of manufacturing and the limiting implication of offering a tangible product that has little potential of creating opportunities for profit generation rather than during the sales process itself, has led to a shift towards offering a product and service bundled together. Bitner (1997) claims that manufacturing companies are simultaneously service companies and therefore, no particular shift in thinking and operating is needed. Nevertheless, according to Mathieu (2001) service strategy is a complex undertaking encompassing a wide range of undertakings. Moreover, with service strategy being specific on its own, it is not nor easy natural for manufacturing companies to embark on a journey towards servitization.

Based on the focused literature review of servitization, this paper explores the opportunities that the development of the Internet of Things (IoT) brings in terms of quickly reaping the benefits of servitization while relieving the costs incurred by such a shift in strategy.

The shift from offering products to offering integrated product-service bundles has been widely discussed in the literature (Scholl, 2006; Baines et al. 2007; Baines et al. 2009; Roy et al. 2009; Zhen, 2012) however, the subject of the IT-driven servitization remains somewhat unexplored. This applies both to theoretical and empirical research which is the initial motivation to the research presented in this paper.

In this paper we aim to readdress the process of value creation in servitization from the IoT perspective. Based on the focused literature review it can be concluded that even though the subject of IoT has been drawing researchers' attention for some time now the actual implementation of IoT solutions for not only building servitization strategies but also for repositioning themselves in the value chains. Addressing customers' needs cannot be achieved without knowing exactly what kind of services customers want and therefore, customer proximity is one of the most important issues to be addressed while discovering the true preferences and needs of customers regarding both products and services. Companies might chose to gain customer proximity by acquiring organizations that are naturally closer to the end customer and therefore, changing their position within a given value chain. Nevertheless, such strategy is costly, time consuming and frequently not a viable option for companies with modest budgets. Companies may rely on third party agencies while gathering the data on e.g. how customers are using their products. However, methods such as interviews will only provide a fraction of the truth. Companies can also go as far as to witness the process but this 
is only attainable over a given and often short period of time which results in gaining only a fragmented view of the reality.

With the rapid development of the IoT which offers a unique opportunity for companies to gain knowledge about how customers are using their products and consequently, to gain better proximity to customer as well as reshaping their value chains by expanding the scope of the product-service offering. This paper explores the various approaches to value creation through IoT based (powered) servitization. Moreover, the aim is to present an up to date perspective on servitization which acknowledges the disruptions that the advent of IoT brings. The research objective can also be formulated from the perspective of a challenging process of redesigning the value proposition so that it accommodates the benefits of IoT as well as addresses the customer needs as closely as possible. We argue that the application of IoT based solutions is a cost-effective method of crafting a value proposition that will bring companies closer to their final customers which translates into an improvement in fulfilling and even exceeding customer needs (relieving customer pains) and consequently - improved profitability.

The paper is structured as follows. Firstly, a focused literature review is provided, followed with the explorative multiple case study. Based on theoretical and empirical finding the conceptual framework is proposed. The paper closes with conclusions, limitations, and suggestions for further research.

\section{Focused literature review}

Rapid development of technology has been reshaping and changing competitiveness and perception of value chains and value creation long before the advent of the Internet. Porter and Millar (1985) address the issue of building competitive advantage with the help of information technology, and how it transforms the value chain. The authors state that every value activity is composed of physical and an information-processing component. While physical components includes the physical tasks required to perform the activity, the informationprocessing component are the steps required to capture, manipulate, and channel the data necessary to perform the activity. Already in the year 1985 the authors have observed that with the falling costs and rapidly growing capacity of new technologies, industries are moving towards the higher information content in both products and processes. The authors have also predicted the further rapid improvement of technology and therefore, the research by Porter 
and Millar (1985) might be treated as an important introduction to the broader field of technological development reshaping the nature of competition.

According to Porter and Heppelmann (2014) the smart, connected products are currently transforming competition and reshaping industry structure. Moreover, Leminen et al. (2012) claim that the growing popularity of IoT also implies the possibilities for redesigned business models which relates to co-creation of value and redesigning value proposition in the context of IoT as discussed by Mejtoft (2011).

The technological development driving down the costs has caused many industries to move towards higher information content in both product and process (Porter and Millar, 1985; Porter and Heppelman, 2015). This statement can be linked with the context of servitization. The term coined by Rada and Vandermerwe (1988) and it is defined as the process of creating value by adding services to products.

\section{Servitization and $B 2 B$ context}

Baines et al. (2007), Baines et al. (2009), and Neely et al. (2007) refer to servitization in terms of a shift from manufacturing towards offering services that are tightly coupled with products. The authors also state that servitization concept can be approached from the perspective of value creation for different customer needs. The authors outline three categories of services: base, intermediate, and advanced services. By introducing such classification, the authors simultaneously address the development of servitization concept and its important link to creation of value to customer.

Mathieu (2001) provides an overview of the potential benefits and costs that stem from servitization. The author refers to financial gains which are ultimately shaped by company's pricing strategy, the potential in adding value in manufacturing, as well as the potential in reaching competitive equality in case of many manufactured goods.

The creation of a product- service bundle requires a better understanding of customer needs which is best achieved by shortening the distance to customer and creating the understanding of how products are being used (Walters, 2008). It is common for companies operating in the business-to-business (B2B) environments to pursue the strategy of buying in the companies that are naturally closer to the final customer in order to quickly tap into the new expertise and 
to change their position in the value chain. While such a strategy is certainly a fast and effective one, it is certainly not a cost effective option and therefore, not universally applicable.

\section{Technological aspects of IoT}

Internet of things includes a technical architecture enabling the communication link from smart products to users. According to Gubbi et al. (2013) there are three main components that enable IoT:

(1) Hardware - a collection of sensors, actuators, and embedded communication hardware

(2) Middleware - on demand storage and computing tools for data analysis

(3) Presentation - visualization and interpretation tools, novel, easy to use, can be widely accessed

Figure 1 outlines the main components of IoT as proposed by Gubbi et al (2013).

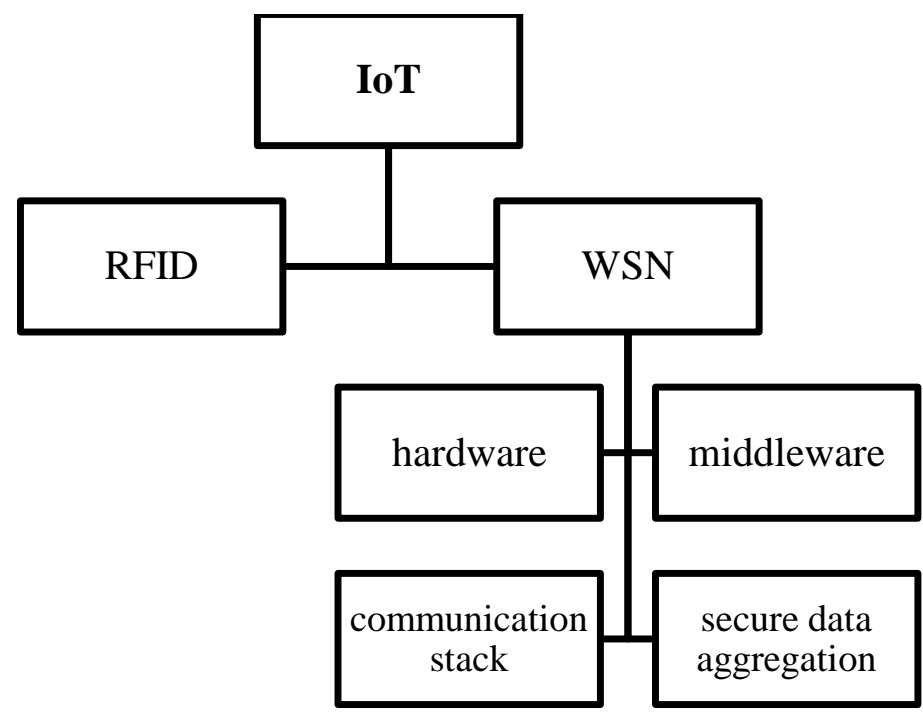

Figure 1. Main components of IoT. Adapted from Gubbi et al. (2013).

The authors state that IoT is essentially composed of Radio Frequency Identification (RFID) and the Wireless Sensor Networks (WSN). While RFID enables design of microchips for wireless data communication, while WSN are low cost, low power miniature devices for use in remote sensing applications. Gubbi et al. (2013) outline the following components of WSN: 
- Hardware, consisting of sensor interfaces, processing units, transceiver units, and power supply

- WSN communication stack enabling communication between the nodes

- Middleware mechanism combining cyber infrastructure with a Service Oriented Architecture (SOA)

- Secure Data Aggregation which is used securing data as an essential element of WSN functioning in the long term

\section{IoT and business ecosystems}

Connectedness of devices which implies connectedness of things can be considered from the perspective of networks and ecosystems which well highlights the scope of IoT. The idea of ecosystems was initially coined to refer to a biological phenomenon, and gradually expanded into the business context (Wiesner et al. 2013).

Mazhelis et al. (2012) refer to IoT ecosystems where the core is built around the interconnection of tangibles- things with the virtual world- the Internet. The authors define IoT ecosystem as a "special type of business ecosystem which comprises of a community of interacting companies and individuals along with their socio-economic environment, where the companies are competing and collaborating by utilizing a common set of core assets related to the interconnection of the physical world of things with the virtual world of Internet” (p.5).

Leminen et al. (2012) approach the subject of IoT from the perspective of business models, and analyse how business models are shaped and created by IoT. The authors analyse business models through the lens of ecosystems (closed private or open networked) and types of customers (business or consumers). The authors argue that the success of IoT is dependent upon the combination of the right technology, business models, as well as acceptability to users. The configuration thereof will ultimately define the actual business model. However, according to Leminen et al. (2012) configuration of business model will become easier and faster with the further development of IoT.

According to Rong et al. (2015) the latest development in the field of IoT postulate discussing the phenomenon in the context of business ecosystems as a natural consequence that stems from the rapidly increasing number of connected devices. Connectivity enables expanding the communication between devices beyond value chains, supply chains, and networks. Therefore, 
it is justified to broaden the scope towards ecosystems. However, as the companies studied in this paper are operating within value chains and therefore, even though the latest developments in the field of IoT are acknowledged, value chains still remain in focus.

\section{IoT and competitive cost of servitization}

Mathieu (2001) claims that servitization strategy might be utilized to build and maintain competitive advantage even in the long run. Service components added to tangible goods also offers an ample opportunity to influence customers' purchasing decisions which Mathieu (2001) translates into the new marketing benefits which, in the long run lead to repeated sales and building lasting relationships with customers . This could be attained by offering the increasingly coveted complete solutions rather than simple after sales services (Johansson and Olhager, 2004).

Mathieu (2001) also outlines certain challenges that stem from servitization costs that should be taken into consideration while deciding whether servitization strategy is a viable option. The author refers to the two most important types of cost- competitive and political. From the perspective of the research presented in this paper, the analysis of competitive cost, especially in the context of IoT powered servitization is important.

Mathieu (2001) claims that competitive costs usually unravel themselves as organizations enter the previously unexplored fields (in this case the field of servitization). As the amount of new competitors increases rapidly, organizations need to build their own competitive advantage which naturally incurs costs which might be difficult to estimate, especially in the very beginning of the "servitization journey". Mathieu (2001) makes an important reference to the fact that while service providers are naturally more apt to master the two main drivers of competitive advantage: economies of scale and learning, while manufacturers shifting towards servitization are forced to maintain and develop both manufacturing and service related competencies. Mathieu (2001) claims that despite of the seemingly disadvantageous position; manufacturing organizations might still build their competitive advantage upon the extent of linkages between goods and service activities. In other words, manufacturing companies are able to base their competitive advantage upon their experience as well as the lasting image which has been built through their goods offering. Moreover, Mathieu (2001) claims that since manufacturing organizations often control both design, development, and the production of the 
offered goods, they have an ample opportunity of offering a unique selection of services which might potentially be difficult to copy by the competitors. Moreover, the ownership of the aforementioned processes might also serve as an ideal basis of crafting services that would truly bring value to customers.

Based on Mathieu's (2001) we wish to extend the discussion on servitization by adding the technological aspect expressed in terms of the IoT. As this paper aims to explore the opportunities for creating value to customers and changing firm's position in the value chain, it is important to contrast the challenges of servitization with the opportunities that the technological development brings. The potential of creating value based on the availability of the data regarding how products are being used, which has not been available in such scale before. By learning and understanding how customers really use products, the related services can be crafted with greater attention regarding the fulfillment and even exceeding the customer needs.

\section{IoT and value creation in servitization context}

The research presented by Porter and Millar (1985) is among the initial attempts to address the question of how the technological development changes industry structure as well as reshapes the process of value creation. The research presented by the authors is among the first attempts to explore the impact of technological development on companies and their competitiveness in particular. The authors focus on value creation in particular and how it can be revolutionized with the help of technology.

Some thirty years later, with the technological development advancing at the high speed and after the third wave of the IT-driven competition the subject of value creation still remains valid (Dominguez-Péry et al. 2013) and moreover, it seems to be changing again to even a greater extent, all this thanks to the concept of the Internet of Things (IoT) becoming more and more widespread. 
According to Opresnik et al. (2013) during servitization an important layer of value creationthrough the information, which constitutes a process called informatization. The authors highlight that servitization is a data intensive process and therefore, certain procedures for exploiting data need to be developed and offered, which implies the new revenue streams for manufacturing companies. Opresnik et al. (2013) state that organizations might analyze the gathered data in-house, using business intelligence techniques or alternatively, the raw data might be resold to other entity.

Opresnik and Taisch (2015) also mention an important and rapidly growing phenomenon of organized collaboration in the process of servitization. The authors outline certain value creation-related motives for collaboration that stem from the laws of synergy- enterprises gain competitive advantage as the value of resources, related skills, and competences exceeds the sum of the assets.

\section{Value creation through operational reliability}

Duran (2000) defines operational reliability as a flexible process that optimizes people, processes and technology through which companies can become more profitable by maximizing availability and value addition of producing assets. Reliable operations are crucial element of successful businesses, and the notion thereof is particularly important in case of complex, demanding operations where costs of non-conformities are tremendous (e.g. oil and gas industry).

According to Schuman and Brent (2007) there are four key elements of operational reliability: (1) human reliability, (2) equipment reliability, (3) equipment maintainability, and (4) process reliability. The authors claim that the four elements need to be integrated in order to ensure the comprehensive maintenance approach.

\section{Servitization and the value chain context}

Porter (1998: 36) defines value chain as a "collection of activities that are performed to design, produce, market, deliver, and support its product". Moreover, the author claims that a value chain of a firm is a reflection of the chosen strategy and the approach to the implementation thereof. Therefore, value chain will differ between organizations and those differences are 
usually the source of competitive advantage. According to Michel et al. (2008) adding services to already well-established product offering are usually utilized to create the desired differentiation upon which serves as a basis for building competitive advantage.

According to Porter (1998) value activities are the building block of competitive advantage, and the author outlines two types thereof: primary and support activities. Primary activities are all those activities that are necessary to physical creation of a products, sale, transfer to the buyer, while the role of the second types of activities is to support all the primary activities by providing purchased inputs, technology, human resources and various firm wide functions (Porter, 1998).

Walters and Lancaster (2000) claim that creation of value is achieved by the identification and understanding of customer benefits and costs as well by combining organizational knowledge and learning with structures that facilitate response and delivery. Raddats and Easingwood (2010) highlight the importance of moving from service strategies that are based solely on company's products towards strategies that are closely aligned with customer's operational environments. Kowalkowski (2005) refers to a similar approach as "customer centricity".

In summary, in the context of value chain and value creation two main challenges can be identified. Firstly, the necessity to offer services that is closely related to the actual customers' needs. Secondly, the proposed service offering that should allow for differentiation that, in turn, serves as a basis for building competitive advantage. With the rapid technological development and the advent of the IoT companies are granted with the possibility to effectively tackle those challenges.

\section{Beyond value chains- value creation logic and its implications}

Porter's (1998) well established and acknowledged logic of value chains needs to be extended with a broader view upon value creation logic that extends the commonly used notion of chains Stabell and Fjeldstadt (1998) propose a configuration of value creation in terms of value chains, shops, and networks, which differ depending on the logic of value creation. While value chains are about transforming inputs into products, value shops are focused on solving and resolving customer problems, and value networks connect customers. According to Stabell and Fjeldstadt (1998), in case of value chains strategic positioning aimed at creating competitive advantage is an issue of choosing a suitable configuration of product scope, market scope, and value system 
scope. In the case of value shops, potential for strategic positioning is exploited through a combination of product scope and business value system scope, as well as problem incorporation. The authors also claim that in the case of value creation networks value is derived from service, service capacity, and service opportunity. Strategic positioning options comprise of horizontal and vertical integration.

\section{Vertical and horizontal integration}

According to Baines et al. (2011) vertical integration can be defined by "the extent to which a firm owns and takes responsibility for its upstream suppliers and its downstream customers" (p.948). Vertical integration allows for a better control over the value chains and increases the potential for profit generation. Schmenner et al. (2009) claims that servitization in the context of vertical integration is a viable option for advanced services which are close to manufacturer's products, and servitization of such kind is often labelled as a product-centric servitization. In case of product-centric servitization manufacturer takes care of e.g. maintenance activities previously performed by customer.

There is not much of significant evidence on horizontal integration in the context of servitization and Ensign (1998) mentions that some researchers doubt that horizontal organizations exist. Raddats and Easingwood (2010) define horizontal integration as manufacturers involvement in developing services linked to other original equipment manufacturers. Therefore, the authors highlight that in order to successfully perform in horizontally integrated servitization, manufacturers must be able to develop new capabilities that imply reaching beyond traditional design and manufacturing capabilities.

Both vertical and horizontal integration in servitization require investments in terms of time and money and it is rather a complex decision and an element of each individual company to decide on the exact servitization strategy. However, with the development of information technology, opportunities for value creation need to be revisited taking into consideration the advent of real-time communication between devices supplementing communication between people. 
Haller et al. (2009) define Internet of Things as a world of physical objects being seamlessly integrated into the information network, and where physical objects can become active participants. Internet of Things stands for suppling devices with sensors through which they are given the ability to communicate. This implies the possibility to create a network of things which are able to communicate with each other with little or no help from humans.

Porter (2014) calls this the third wave of IT-driven competition. Before any actual reference to IoT reshaping competition can be made it is important to briefly mention the development of the Internet which initially implied improved (and gradually) unlimited and extremely fast (almost real-time) communication between people. This stage was followed by the emergence of Web 2.0 which enabled improved communication and dialogue through social media as users were given an opportunity to create and share content rather than passively viewing it. IoT followed the development of Web 2.0 and the term itself was coined by Kevin Ashton in already in the year 1999. The term Internet of Things is used to refer to a general network of things linked together by IT components (sensors) that enable information exchange among them. Therefore, today we no longer refer to people communicating with the help of IT solutions, but also things.

Rather than using the term "things" it makes much sense to discuss the smart, connected products (Porter and Heppelmann, 2014) and reflect upon the far reaching consequences that this novel type of connectivity implies. The authors introduces the concept of the new technology stack which comprises of multiple layers such as new product hardware, embedded software, connectivity, a product cloud consisting of software running on remote servers, an array of security tools, a gateway for external information sources, and integration with enterprise business system. In other words, if the companies wish to reap the benefits of IoT in their product-service strategies, the appropriate technological stack needs to be created first. According to Porter and Heppelmann (2014) there are ten new strategic choices. In order to determine the new overall strategic positioning, organizations need to address the tradeoffs between the strategic choices and naturally, these choices will be dependent upon the specific characteristics of a company.

Table 1 presents a summary of issues and their implications to strategy that should be addressed while building a strategy around IoT. Clear choices in each of those dimensions will help companies to build their servitization strategies based on IoT. 
Table 1. IoT and its strategic implications. Adapted from Porter and Heppelmann (2014).

\begin{tabular}{|c|c|}
\hline STRATEGIC ISSUE & STRATEGIC IMPLICIATIONS \\
\hline Selecting smart capabilities & $\begin{array}{l}\text { Race for constantly adding might lead to } \\
\text { blurred strategic differences and creation of } \\
\text { zero-sum competition }\end{array}$ \\
\hline $\begin{array}{l}\text { Embedding functionalities- product and } \\
\text { cloud }\end{array}$ & $\begin{array}{l}\text { Functionalities embedded in product will } \\
\text { lead the costs of every product however, in } \\
\text { some cases it cannot be avoided (e.g. if a } \\
\text { product is required to shut itself down in } \\
\text { case of emergency) }\end{array}$ \\
\hline Open vs closed system & $\begin{array}{l}\text { Closed system creates competitive } \\
\text { advantage by allowing a company to control } \\
\text { and optimize the design of all parts of the } \\
\text { system relative to one another. On the other } \\
\text { hand, open system enables a faster rate of } \\
\text { applications development and system } \\
\text { innovation as multiple entities contribute }\end{array}$ \\
\hline $\begin{array}{l}\text { Development of capabilities performed in } \\
\text { house or externally }\end{array}$ & $\begin{array}{l}\text { Organizations should find a balance } \\
\text { between developing certain layers of } \\
\text { technology in house while simultaneously } \\
\text { outsourcing certain capabilities }\end{array}$ \\
\hline Data to be captured, secured and analyzed & $\begin{array}{l}\text { Maximizing the value of offering will be } \\
\text { dependent on the decisions regarding } \\
\text { product data. The balance between the } \\
\text { investment in e.g. sensors and the amount of } \\
\text { data collected is crucial to successful } \\
\text { implementation of the IoT powered } \\
\text { servitization. }\end{array}$ \\
\hline Ownership and access rights to product data & $\begin{array}{l}\text { Certain restrictions shall apply as data } \\
\text { becomes a valuable commodity }\end{array}$ \\
\hline $\begin{array}{l}\text { Full or partial disintermediation of } \\
\text { distribution channels/service networks }\end{array}$ & $\begin{array}{l}\text { Better knowledge of customers reduces the } \\
\text { need to intermediaries and service partners. } \\
\text { Companies must decide how to address the } \\
\text { newly attained customer proximity. }\end{array}$ \\
\hline Business model change & $\begin{array}{l}\text { The obvious changes in value propositions } \\
\text { might lead to the existing business models } \\
\text { becoming not obsolete and uncompetitive. }\end{array}$ \\
\hline $\begin{array}{l}\text { Entering new markets by monetizing } \\
\text { product data through selling it to outside } \\
\text { parties }\end{array}$ & $\begin{array}{l}\text { Capturing product data might open new } \\
\text { opportunities for profit generation. The } \\
\text { dilemma is whether the data should be } \\
\text { available to entities that have no connection } \\
\text { to products. }\end{array}$ \\
\hline
\end{tabular}


The strategic decisions summarized in table 1 serve as a basis for presenting and exploring the IoT powered servitization strategies of the studied companies operating in the B2B environments.

The consecutive chapters of this paper are devoted to presenting the methodology and research design as well as exploring the IoT powered strategies especially in the context of the important challenge of strategic shift and changes in value chain which can be explained by the fact that manufacturing organizations moving towards services would have to rethink their value chains towards differentiation and "customer centrism".

\section{Methodology}

The research presented in this paper focuses on the companies operating within the B2B environment. Additionally, for the purpose of addressing the process of organization's repositioning within value chain the companies selected for the study.

The study is based on the multiple cases where selected companies were analyzed in-depth. Data collection was primarily based on the analysis of historical data and semi-structured interviews with managers responsible for conducting the shift towards servitization. The focus of data collection and analysis was in qualitative input as such data was deemed the most appropriate from the perspective of addressing the research objectives stated in this paper.

According to Stake (2006) multiple case analysis should be guided by the set of phenomenon which will be addressed in each and every case. The author also claims that multiple case study method is also directed by the fundamental question of what helps us understand the studied phenomenon. Therefore, even though the cases are presented one by one, as each case should be understood in more depth and its meaning in the context of the studied phenomenon, the aim is also to analyze them holistically towards providing an explanation of the research objective. Stake (2006) also claims that multiple case study method is useful while addressing more than one research question. 
The companies were selected on the basis of their advancement in IoT powered servitization. Company $\mathrm{A}$ is a large company manufacturing sheet metal machines which is currently undergoing a transformation towards servitization based on the development of their fleet management system. Company $\mathrm{B}$ is a large multinational company providing complete lifecycle power solutions for energy markets. Company $\mathrm{C}$ is a large multinational company offering power and automation technologies. The research presented in this paper is focused on the transformers business unit.

\section{Case analysis and results}

In order to provide a more exact presentation of the case companies, the studied servitization strategies were described and classified according to the model proposed by Raddats and Easingwood (2010). The authors outline the four main types of servitization strategies:

(1) Product-attached services on own products (e.g. installation, training, support)

(2) Operation services on own products (e.g. managed services, asset availability)

(3) Product attached services on own and third party products (e.g. installation, training support)

(4) Vendor-agnostic operation services (e.g. systems integration, technical consultancy)

Furthermore, the analysis of "IoT powered" servitization strategies is presented in this paper is analyzed from the perspective of several strategic decisions and their potential implications which are summarized in table 1.

The companies selected for the analysis are large-size global organizations operating globally. The companies initially established themselves as manufacturers of physical, tangible products however, with time shifted their focus towards enriching their offering complementary services which, with the help of the technological advancement, are gradually evolving into the IoT powered.

\section{Company A}

Company A is a multinational provider of machinery for sheet metal processing. The origin of the company is built on mechanical engineering and manufacturing knowledge. The focal areas 
have been designing and building high quality machines for cutting, punching, shearing and bending sheet metal. During the past decades the focus of the company has changed from individual machines to larger systems, consisting of several machines in a production line. Customers of the company A are operating in various sectors, including automotive, aerospace, HVAC and smaller sub-contractors. Service business of the company has been based on maintenance contracts and spare part sales. As complexity of the products has been increased and scope of supply extended, need for technical support, training and advisory services has increased.

The product - machinery or product line - is an example of investment good in business-tobusiness setting. The machinery is highly automated and includes computers and sensors. Previously, Internet connection to machines is a standard feature, but it has been mainly used to support the internal work and not as media to increase the product. Company $\mathrm{A}$ has introduced a strategy to build product-service system around the internet connection of the machinery. Life-cycle of a typical system is long and contact with the customer is not very frequent after a successful commissioning. The initial system configuration may change due to customer product portfolio changes and what has been optimized in the commissioning phase may not be optimal any more.

The developed IoT solution provides an opportunity to see actual production and daily key performance indicators. This information is collected to a centralized cloud system, which provides a view to both end-customer as well as Company A service organization. As the solution is focusing on hierarchy of machines at different location it is called a fleet management system.

Table 2. Case analysis- company A.

\begin{tabular}{|l|l|}
\hline STRATEGIC ISSUE & STRATEGIC IMPLICIATIONS \\
\hline Selecting smart capabilities & $\begin{array}{l}\text { Remote view on customers production line } \\
\text { performance }\end{array}$ \\
\hline $\begin{array}{l}\text { Embedding functionalities- product and } \\
\text { cloud }\end{array}$ & $\begin{array}{l}\text { Fleet view by collecting operational data in } \\
\text { centralized cloud. } \\
\text { Supporting commissioning and training } \\
\text { phase as part of investment. }\end{array}$ \\
\hline
\end{tabular}




\begin{tabular}{|c|c|}
\hline & $\begin{array}{l}\text { Part of service level and maintenance } \\
\text { agreements }\end{array}$ \\
\hline Open vs closed system & $\begin{array}{l}\text { Limited to end-customers as a portal view, } \\
\text { limited within Company A, no external } \\
\text { solution providers. }\end{array}$ \\
\hline $\begin{array}{l}\text { Development of capabilities performed in } \\
\text { house or externally }\end{array}$ & $\begin{array}{l}\text { Internal development, as product is } \\
\text { automated and connected for other needs as } \\
\text { well. }\end{array}$ \\
\hline Data to be captured, secured and analyzed & $\begin{array}{l}\text { Factory operations information: production } \\
\text { orders, materials, processing times, setup } \\
\text { times, alerts, performance data } \\
\text { Part information, bill-of-materials }\end{array}$ \\
\hline Ownership and access rights to product data & $\begin{array}{l}\text { Service contracts giving access to Company } \\
\text { A to use data in remote support and } \\
\text { advisory. }\end{array}$ \\
\hline $\begin{array}{l}\text { Full or partial disintermediation of } \\
\text { distribution channels/service networks }\end{array}$ & No available data \\
\hline Business model change & $\begin{array}{l}\text { Focus on solutions and operational } \\
\text { performance of the fleet by using software. } \\
\text { Continuous connection with customers }\end{array}$ \\
\hline $\begin{array}{l}\text { Entering new markets by monetizing } \\
\text { product data through selling it to outside } \\
\text { parties }\end{array}$ & No available data \\
\hline Expanding company's scope & $\begin{array}{l}\text { Toward service and maintenance from } \\
\text { physical product. }\end{array}$ \\
\hline Value creation logic & $\begin{array}{l}\text { Within value chains } \\
\text { Increased performance of the equipment in } \\
\text { combination with optimized maintenance } \\
\text { ensures lower OPEX. }\end{array}$ \\
\hline
\end{tabular}

The main value creation logic change for the Company A is changing the position in the value chain closer to customer operations. Being able to monitor and understanding daily situations at the end-customer shop floor allows performance based contracts and remote support to customer to optimize the production. This kind of benefit shifts the value creation of the product toward intangible product-service. The value for the customer can be measured in the long run as reduced operating costs.

\section{Company $B$}


Company $\mathrm{B}$ is a provider of power generators and supplying offering from machinery to complete power plants. Depending on the delivery project the scope of supply may vary from individual power generators to complete gas operated power plants. Power generators are critical equipment which needs to ramp-up a certain guaranteed amount of electricity in a reasonably short time range. For this reason both scheduled and pre-emptive maintenance are important to guarantee the performance and reliability. Outage situations may be costly and involve risk.

Company B acts as a manufacturer of products and also as a provider of solutions (power system design and installations) as well as operations and services (maintenance and repair). The company has redeveloped their condition based maintenance which replaces the scheduled maintenance activities with maintenance that is based on the actual performance of a product rather than predictions. Condition-based maintenance (CBM) has been possible to implement with the development of IoT. CBM system collected data from the machinery and compares the sensor values to upper and lower control limits and more complicated trends and patterns. Daily data values are transmitted to central CBM team at the Company B. An analysis is conducted for each machine and periodical reports are sent to customer to demonstrate the performance of the system. In case of problems occurring, remote advisory service can be provided proactively as alerts are sent to customers and responsible service people.

Condition based maintenance is offered as an option for larger projects. Typically, CBM is part of larger contracts which may include spare parts, scheduled maintenance, and support personnel both remotely and locally. CBM may be needed to support performance levels guaranteed in sales contracts.

Table 3. Case analysis- company B.

\begin{tabular}{|l|l|}
\hline STRATEGIC ISSUE & STRATEGIC IMPLICIATIONS \\
\hline Selecting smart capabilities & $\begin{array}{l}\text { Remote view on assets for maintenance } \\
\text { purposes. }\end{array}$ \\
\hline $\begin{array}{l}\text { Embedding functionalities- product and } \\
\text { cloud }\end{array}$ & $\begin{array}{l}\text { View on machinery, advisory services from } \\
\text { centralized support team. }\end{array}$ \\
\hline
\end{tabular}




\begin{tabular}{|l|l|}
\hline Open vs closed system & Closed system, based on contract. \\
\hline $\begin{array}{l}\text { Development of capabilities performed in } \\
\text { house or externally }\end{array}$ & Internal development \\
\hline Data to be captured, secured and analyzed & $\begin{array}{l}\text { Daily statistics of operations: energy } \\
\text { produced, fuel consumed, efficiency. } \\
\text { Machine parameters and sensor values } \\
\text { Ambient environment }\end{array}$ \\
\hline Ownership and access rights to product data & Data owned by the end-customer \\
\hline $\begin{array}{l}\text { Full or partial disintermediation of } \\
\text { distribution channels/service networks }\end{array}$ & $\begin{array}{l}\text { Service contracts and localized service } \\
\text { network. }\end{array}$ \\
\hline Business model change & Focus on operations and maintenance \\
\hline $\begin{array}{l}\text { Entering new markets by monetizing } \\
\text { product data through selling it to outside } \\
\text { parties }\end{array}$ & $\begin{array}{l}\text { Possibility to utilize real operational data for } \\
\text { R\&D purposes within Company B }\end{array}$ \\
\hline Expanding company's scope & $\begin{array}{l}\text { High performing reliable power plant } \\
\text { justifies higher investment costs }\end{array}$ \\
\hline Value creation logic & $\begin{array}{l}\text { Within value chains } \\
\text { Condition based maintenance reduces risk } \\
\text { of expensive non-planned interruptions. } \\
\text { Improved asset utilization for customer }\end{array}$ \\
\hline
\end{tabular}

Value creation in the case of company B is provided by improving the reliability of the machinery. This can increase maintenance business for company B in certain extent, but the main value proposition is for end customer in form of improved total cost of ownership.

\section{Company $C$}

Company $\mathrm{C}$ is a business unit in large company providing technology to power generation and distribution. The product of Company $\mathrm{C}$ is large power transformers used in electricity distribution networks. Power transformer is an expensive component with long expected lifecycle approaching 30 to 40 years. Correct use of the product, in terms of transmitted power, ambient temperature, quality of electricity and proper maintenance guarantee reliable operations. Traditionally, automation level in power transformers has been low. As sensor technology - related to currents, voltages and frequencies, temperatures and oil quality are based on electronics, data logging devices have been introduced to track conditions. 
Power transformers could be part of larger infrastructural development projects or simply replacing components in existing networks. Typically, the product is purchased by a local utility company based on defined technical specification and tendering processes. The scope of supply is often limited to the physical product and service is conducted locally by the customer itself or local service providers. Access on actual operational data is difficult to gather and may require manual operations.

Company $\mathrm{C}$ built an automated logging device with Internet connection. Transformer is connected to the utility local intranet and providing real-time view for the end-user to see each power transformer operation. Proper use and avoiding operational faults such as boiling cooling oil by transmitting too much power can increase significantly the expected life-cycle of the product. Information can be shared with local external maintenance personnel of the utility. Company $\mathrm{C}$ can ask for data access from the end user and provide insights on usage metrics.

Table 4. Case analysis- company C.

\begin{tabular}{|l|l|}
\hline STRATEGIC ISSUE & STRATEGIC IMPLICIATIONS \\
\hline Selecting smart capabilities & $\begin{array}{l}\text { Remote view on asset condition for the end- } \\
\text { user operations and maintenance. }\end{array}$ \\
\hline $\begin{array}{l}\text { Embedding functionalities- product and } \\
\text { cloud }\end{array}$ & $\begin{array}{l}\text { Ensuring proper use of transformer } \\
\text { Maintenance support }\end{array}$ \\
\hline Open vs closed system & $\begin{array}{l}\text { Closed system between asset owner and the } \\
\text { physical product. }\end{array}$ \\
\hline $\begin{array}{l}\text { Development of capabilities performed in } \\
\text { house or externally }\end{array}$ & $\begin{array}{l}\text { Solution developed by using external } \\
\text { provider }\end{array}$ \\
\hline Data to be captured, secured and analyzed & $\begin{array}{l}\text { Each phase voltage, current, frequency } \\
\text { Ambient temperature } \\
\text { Oil temperature } \\
\text { Cooling fan operations }\end{array}$ \\
\hline Ownership and access rights to product data & $\begin{array}{l}\text { Data stored in local product memory, no } \\
\text { centralized cloud system. }\end{array}$ \\
\hline $\begin{array}{l}\text { Full or partial disintermediation of } \\
\text { distribution channels/service networks }\end{array}$ & $\begin{array}{l}\text { Utility as end user } \\
\text { Local external maintenance companies }\end{array}$ \\
\hline Business model change & $\begin{array}{l}\text { Additional feature for product to support } \\
\text { better use of for the utility. }\end{array}$ \\
\hline
\end{tabular}




\begin{tabular}{|l|l|}
\hline $\begin{array}{l}\text { Entering new markets by monetizing } \\
\text { product data through selling it to outside } \\
\text { parties }\end{array}$ & $\begin{array}{l}\text { Intangible feature of the product: self- } \\
\text { guiding and early warning on misuse }\end{array}$ \\
\hline Expanding company's scope & $\begin{array}{l}\text { Understanding of actual operations in } \\
\text { different locations and uses }\end{array}$ \\
\hline Value creation logic & $\begin{array}{l}\text { Increased life-cycle of the product yielding } \\
\text { lower OPEX per kWh. }\end{array}$ \\
\hline
\end{tabular}

Value creating for the Company $\mathrm{C}$ is currently related to better control of the physical product and helping end-user to manage both operations and maintenance. Increased life-cycle of asset should improve the investment cost divided over the years.

Based on the analysis of the three cases a graphical summary for extending value chain with the help of IoT was proposed (figure 2). Table 5 is a graphical summary of how the IoT powered servitization enabled the studied companies to expand the scope of the value creation beyond the traditional design and manufacturing. With the advent of IoT companies were able to expand their scope of value creation by being able to operate within the field of product use, providing solutions as well as operations and services.

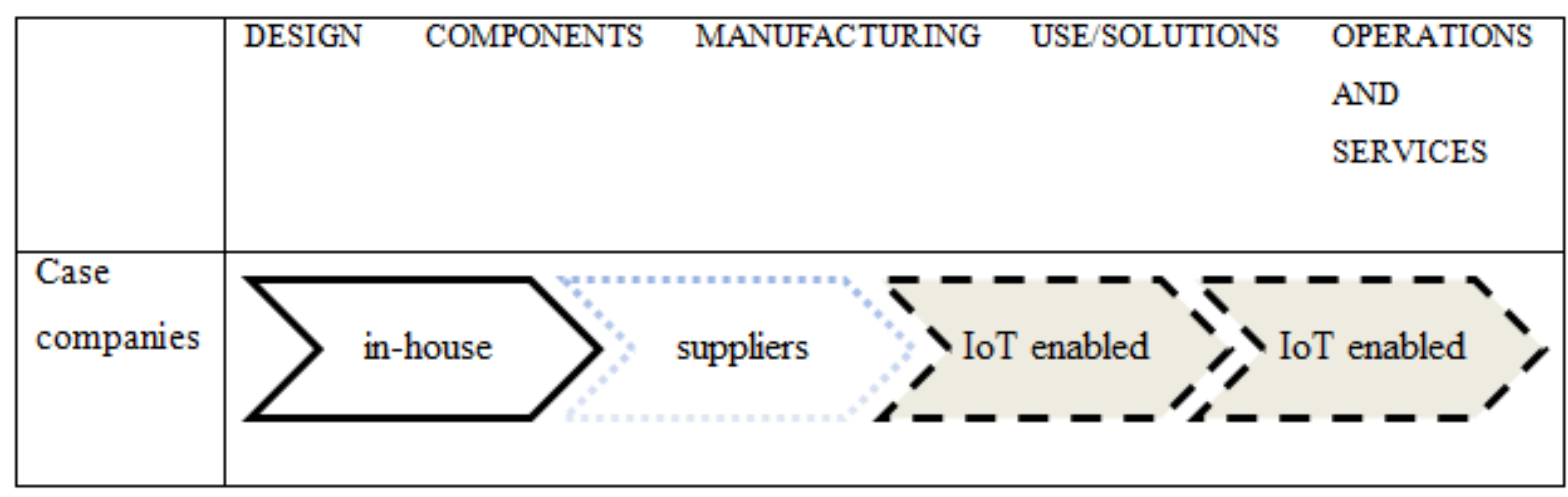

Figure 2. Summary of case analysis- value chain perspective.

Table 6 provides a summary of the studied companies in terms of the service main functionality, means of measuring value proposition, IoT functionality as well monetarization of service (means of profit generation). Table 6 is aimed at highlighting that by adding a technological component and enabling IoT powered servitization companies are no longer 
offering a tangible product but rather a complete solution where software plays an important role and significantly adds value.

Table 5. Summary of case companies.

\begin{tabular}{|l|l|l|l|l|}
\hline & $\begin{array}{l}\text { Service main } \\
\text { functionality }\end{array}$ & $\begin{array}{l}\text { Value } \\
\text { proposition } \\
\text { measured }\end{array}$ & $\begin{array}{l}\text { IoT } \\
\text { functionality }\end{array}$ & $\begin{array}{l}\text { Monetarization } \\
\text { of service }\end{array}$ \\
\hline $\begin{array}{l}\text { Company A - } \\
\text { Sheet metal } \\
\text { machinery }\end{array}$ & $\begin{array}{l}\text { Operations } \\
\text { support and } \\
\text { optimization }\end{array}$ & $\begin{array}{l}\text { Reduced unit } \\
\text { cost (EUR/pcs) }\end{array}$ & $\begin{array}{l}\text { Production/opera } \\
\text { tions data } \\
\text { captured for } \\
\text { OEM }\end{array}$ & $\begin{array}{l}\text { Product sold as } \\
\text { investment } \\
\text { Monthly fee }\end{array}$ \\
\hline $\begin{array}{l}\text { Company B - } \\
\text { Power } \\
\text { generators }\end{array}$ & $\begin{array}{l}\text { Maintenance } \\
\text { support }\end{array}$ & $\begin{array}{l}\text { Reduced risks of } \\
\text { outage, penalty } \\
\text { costs }\end{array}$ & $\begin{array}{l}\text { Detailed machine } \\
\text { level sensor data }\end{array}$ & $\begin{array}{l}\text { Part of larger } \\
\text { service contract }\end{array}$ \\
\hline $\begin{array}{l}\text { Company C - } \\
\text { Transformers }\end{array}$ & $\begin{array}{l}\text { Local } \\
\text { maintenance } \\
\text { support }\end{array}$ & $\begin{array}{l}\text { Increased } \\
\text { product life- } \\
\text { cycle }\end{array}$ & $\begin{array}{l}\text { Connecting } \\
\text { transformer to } \\
\text { intranet access }\end{array}$ & $\begin{array}{l}\text { Option in a } \\
\text { product, no } \\
\text { subscription fee }\end{array}$ \\
\hline
\end{tabular}

\section{Toward the conceptual framework}

Figure 3 summarizes the theoretical and empirical consideration presented in this paper in a form of a conceptual framework. The framework is divided into the three parts with each representing a phase in the technological development and it influence upon the creation of new opportunities of adding value to customer which, in turn, calls for a redesign of value chains by adding stages where value creation occurs while acknowledging the extension of value chains with the new opportunities for value creation that are only possible thanks to the IoT development.

The initial stage of servitization is presented in the context of the Internet of Services and the Internet of People where data are essentially exchanged between people and the exchange is facilitated by the information technology. All the studied companies have been following a common path of supplementing the well-established product offering with services crafted based on the unique expertise that stem from being manufacturer.

Even though such an approach is justified and evolves with the development of an organization, it has a certain drawback caused by the limited availability of data regarding how products are 
used. In other words, manufacturers are limited in their ability to plan and develop services that would be based on the actual usage of products by the end customers. With the rapid technological development which enables communication between devices, collection of data and analysis thereof became not only possible but also affordable. Therefore, with the help of IoT, the studied companies were able to address the needs of their customers, which imply being able to offer services that might serve as a competitive advantage. The worth of the data exchanged by machines lays in the information they carry and the potential use thereof as well as the fact that they are inaccessible for competitors. This is illustrated as a consecutive part of the presented framework (second row of the figure 3). With the advent of IoT and with improving the service offering, companies were able to enrich the existing value chain with innovative value adding activities based on gathering and analyzing data exchanged by machines and devices.

The framework also addresses the answer to the question of how does the value creation is realized in practice with the help of IoT. The framework incorporates the latest findings by Porter and Heppelmann (2015) who suggest the following means of value creation which translate into unique profit creation opportunities:

(1) Shortening the product development cycles - Rather than releasing completely new products regularly, companies can bypass the pressure for frequent product introductions by releasing smaller scale upgrades and enhancements. By doing this customer needs can be fulfilled quicker with an improved precision.

(2) New business models - The expanded opportunities for value creation directly translate into the revisited opportunities of crafting company's value proposition The advent of IoT brings new opportunities for designing and redesigning business models such as cloud-based (Wen and Zhou, 2013). Getting access to a large amount of data is an immediate opportunity for creating new value but also for generating profit as companies might decide to sell the access to data to the third parties.

(3) Supporting customer success - IoT not only enables tailored service offerings but also creates an ample opportunity to advise customers in a variety of matters that are essentially rooted in how products are used. By gathering data on product usage solutions for better utilization or change of equipment can be made which ultimately translates to supporting customer's success. 
(4) Product as a part of a broader system- Products equipped with sensors require suitable software and therefore, they gradually cease existing as a sole tangible entity.

(5) Data analytics - Data analytics is a powerful tool for creating value as well as generating profit. Moreover, the need for data analytics creates a need for skilled workforce in that particular field.

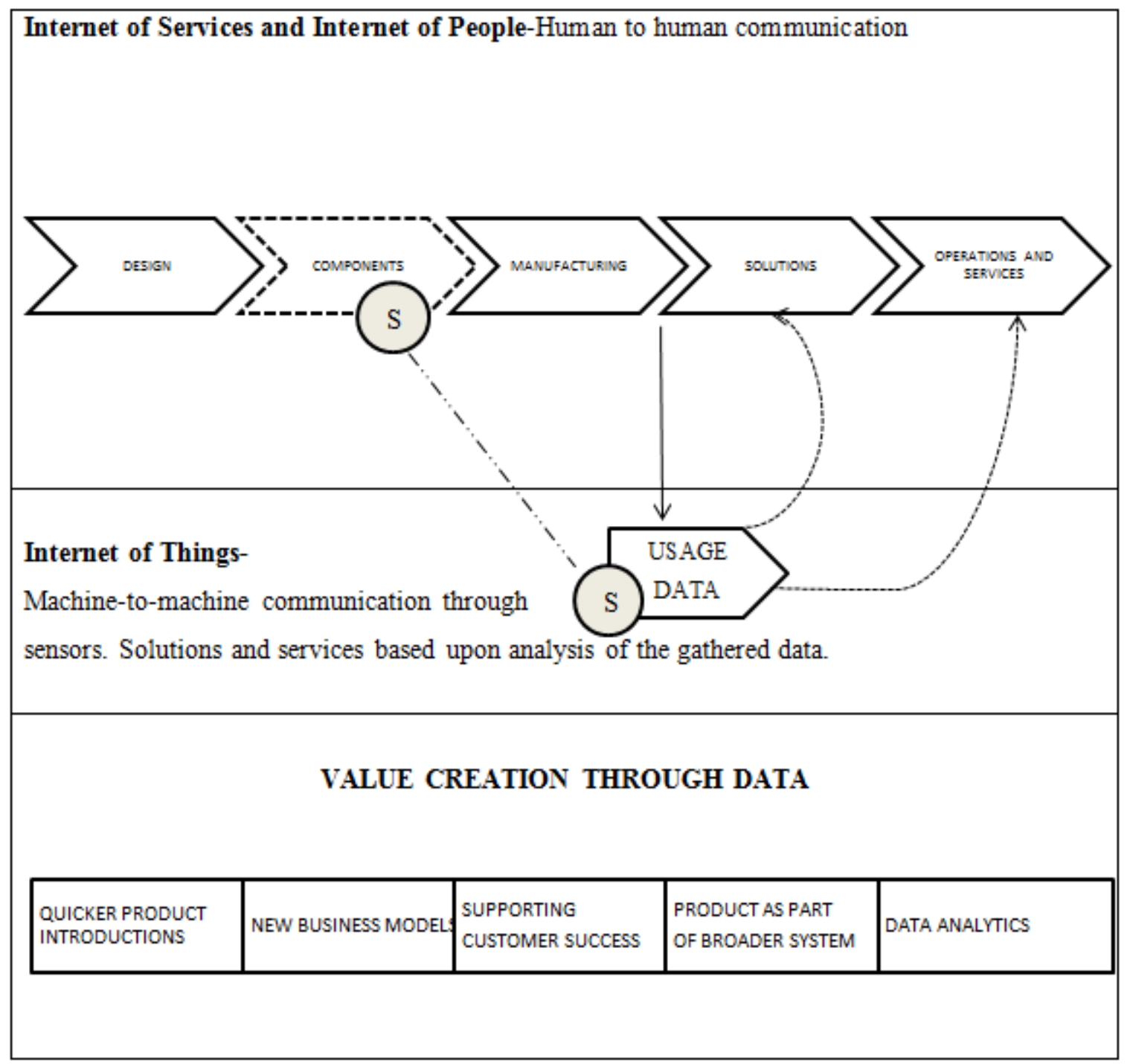

Figure 3. The proposed conceptual framework.

\section{Conclusions, limitations, and further research}

The service offering of the studied companies might be described in terms of predictive maintenance or machines as a service. Both of them are characteristic to the phenomenon known as Industry 4.0 supported by the fourth wave of technological advancement. This transformation is based upon the networked connectivity of sensors, machines, workpieces, 
and IT systems along value chains rather than single enterprises. Connected devices and the rapid interchange of information will ultimately lead to increased manufactured productivity, shift in economics, modified workforce profile, which ultimately leads to a profound change in competitiveness of companies and regions (Rüßmann et al, 2015).

The research presented in this paper explores the benefits of the IoT, and the powerful potential behind the communicating devices. The focused literature review combined with the analysis of cases resulted in the development of a conceptual framework that draws attention to the broader context of utilizing the IoT not only for improving company's service offering but also for reshaping value chains, as well as building company's competitive advantage.

This paper argues that IoT solutions can serve as remarkable tools for building the productservice systems of the future. With the well-planned, and IoT powered servitization strategy companies are able to create a solid competitive advantage based on reliable data on product usage and performance, services can be created or tailored towards increased profitability and improved customer satisfaction.

Certain limitations of the study should also be acknowledged. Firstly, due to the relatively small amount of case companies it is difficult to address the possibility of generalization despite the similarities. Secondly, the companies chosen are of similar size and their road towards servitization was relatively similar and therefore, rather a narrow perspective is presented and therefore, a comparative research in the field would be beneficial.

With the advancement of IoT unique possibilities for value creation and ultimately supporting customer success, the opportunities for new business models are growing rapidly. This will have far reaching consequences on the global economic landscape. The further research into IoT and servitization should be focused on uncovering the unique business models and their impact on economy, technology, and environment.

\section{References}

Baines, T. S., Lightfoot, H. W., Evans, S., Neely, A., Greenough, R., Peppard, J., ... \& Wilson, H. (2007). State-of-the-art in product-service systems. Proceedings of the Institution of Mechanical Engineers, Part B: Journal of Engineering Manufacture, 221(10), 15431552. 
Baines, T., Lightfoot, H., Peppard, J., Johnson, M., Tiwari, A., Shehab, E., \& Swink, M. (2009). Towards an operations strategy for product-centric servitization. International Journal of Operations \& Production Management,29(5), 494-519.

Baines, T. S., Lightfoot, H. W., Benedettini, O., \& Kay, J. M. (2009). The servitization of manufacturing: A review of literature and reflection on future challenges. Journal of Manufacturing Technology Management, 20(5), 547-567.

Baines, T., Lightfoot, H., \& Smart, P. (2011). Servitization within manufacturing: Exploring the provision of advanced services and their impact on vertical integration. Journal of Manufacturing Technology Management,22(7), 947-954.

Bitner, M.J. (1997), Services marketing: perspectives on service excellence, Journal of Retailing, 73(1), 3-6

Dominguez-Péry, C., Ageron, B., \& Neubert, G. (2013). A service science framework to enhance value creation in service innovation projects. An RFID case study. International Journal of Production Economics, 141(2), 440-451.

Duran, J. (2000). What is Operational Reliability.

Ensign, P. C. (1998). Interrelationships and horizontal strategy to achieve synergy and competitive advantage in the diversified firm. Management Decision, 36(10), 657-668.

Gubbi, J., Buyya, R., Marusic, S., \& Palaniswami, M. (2013). Internet of Things (IoT): A vision, architectural elements, and future directions. Future Generation Computer Systems, 29(7), 1645-1660.

Haller, S., Karnouskos, S., \& Schroth, C. (2009). The internet of things in an enterprise context (pp. 14-28). Springer Berlin Heidelberg.

Johansson, P., \& Olhager, J. (2004). Industrial service profiling: Matching service offerings and processes. International Journal of Production Economics, 89(3), 309-320.

Kowalkowski, C. (2005). The Importance of Industrial Service Strategies-Exploring the Service Offering within European Industrial Markets.

Leminen, S., Westerlund, M., Rajahonka, M., \& Siuruainen, R. (2012). Towards iot ecosystems and business models. In Internet of Things, Smart Spaces, and Next Generation Networking (pp. 15-26). Springer Berlin Heidelberg. 
Mathieu,V.(2001). Service strategies within the manufacturing sector: benefits, costs and partnership. International Journal of Service Industry Management, 12(5), 451-475.

Mazhelis, O., Luoma, E., \& Warma, H. (2012). Defining an internet-of-things ecosystem. In Internet of Things, Smart Spaces, and Next Generation Networking (pp. 1-14). Springer Berlin Heidelberg.

Mejtoft, T. (2011, October). Internet of Things and Co-creation of Value. InInternet of Things (iThings/CPSCom), 2011 International Conference on and 4th International Conference on Cyber, Physical and Social Computing (pp. 672-677). IEEE.

Michel, S., Vargo, S. L., \& Lusch, R. F. (2008). Reconfiguration of the conceptual landscape: a tribute to the service logic of Richard Normann.Journal of the Academy of Marketing Science, 36(1), 152-155.

Neely, A. (2007). The servitization of manufacturing: an anlsysis of global trends. 14th European Operations Management Association.

Opresnik, D., Hirsch, M., Zanetti, C., \& Taisch, M. (2013). Information-the hidden value of servitization. In Advances in Production Management Systems. Sustainable Production and Service Supply Chains (pp. 49-56). Springer Berlin Heidelberg.

Opresnik, D., \& Taisch, M. (2015). The value of Big Data in servitization.International Journal of Production Economics, 165, 174-184.

Porter, M. E. (1985). Technology and competitive advantage. Journal of business strategy, 5(3), 60-78.

Porter, M. E. (1998). Cluster and the new economics of competition.

Porter, M. E., \& Heppelmann, J. E. (2014). How smart, connected products are transforming competition. Harvard Business Review, 92(11), 11-64.

Porter, M. E., \& Heppelmann, J. E. (2015). How Smart, Connected Products Are Transforming Companies. Harvard Business Review, 93(10), 96-14.

Porter, M. E., \& Millar, V. E. (1985). How information gives you competitive advantage.

Rada, J., \& Vandermerwe, S. (1988). Servitization of business: adding value by adding service. European Management Journal, 6(4), 314-320. 
Raddats, C., \& Easingwood, C. (2010). Services growth options for B2B product-centric businesses. Industrial Marketing Management, 39(8), 1334-1345.

Rong, K., Hu, G., Lin, Y., Shi, Y., \& Guo, L. (2015). Understanding business ecosystem using a 6C framework in Internet-of-Things-based sectors.International Journal of Production Economics, 159, 41-55.

Roy, R., Shehab, E., \& Tiwari, A. (2009). Product-service systems. Journal of Manufacturing Technology Management, 20(5).

Rüßmann, M., Lorenz M., Gerbert P., Waldner M., Justus J., Engel P., Harnisch M. (2015). Industry 4.0. The Future of Productivity and Growth in Manufacturing Industries BCG (Boston Consulting Group. Available at: https://www.bcgperspectives.com/content/articles/engineered_products_project_busin ess industry_40_future_productivity_growth_manufacturing_industries/ (Accessed on: 30.10 .2015$)$

Schmenner, R. W., Van Wassenhove, L., Ketokivi, M., Heyl, J., \& Lusch, R. F. (2009). Too much theory, not enough understanding. Journal of Operations Management, 27(5), 339-343.

Scholl, G. (2006). Product service systems. Perspectives on Radical Changes to Sustainable Consumption and Production (SCP), 25-43.

Schuman, C. A., \& Brent, A. C. (2005). Asset life cycle management: towards improving physical asset performance in the process industry. International Journal of Operations \& Production Management, 25(6), 566-579.

Stabell, C. B., \& Fjeldstad, Ø. D. (1998). Configuring value for competitive advantage: on chains, shops, and networks. Strategic management journal,19(5), 413-437.

Stake, R. E. (2013). Multiple case study analysis. Guilford Press.

Walters, D., \& Lancaster, G. (2000). Implementing value strategy through the value chain. Management Decision, 38(3), 160-178.

Walters, P. G. (2008). Adding value in global B2B supply chains: Strategic directions and the role of the Internet as a driver of competitive advantage.Industrial Marketing Management, 37(1), 59-68. 
Wen, X., \& Zhou, X. (2014). Servitization of manufacturing industries based on cloud-based business model and the down-to-earth implementary path. The International Journal of Advanced Manufacturing Technology, 1-18.

Wiesner, S., Westphal, I., Hirsch, M., \& Thoben, K. D. (2013). Manufacturing Service Ecosystems. In Advances in Production Management Systems. Competitive Manufacturing for Innovative Products and Services (pp. 305-312). Springer Berlin Heidelberg.

Zhen, L. (2012). An analytical study on service-oriented manufacturing strategies. International Journal of Production Economics, 139(1), 220-228. 